\begin{tabular}{|c|}
\hline $\begin{array}{r}\text { 2. To: (Receiving Organizati } \\
\text { Distribution }\end{array}$ \\
\hline 5. Proj./Prog./Dept./Div.: \\
\hline $\begin{array}{l}\text { Tank } 241-A W-104 / \text { River } \\
\text { Protection } \\
\text { Project/DD\&I/Process } \\
\text { Engineering }\end{array}$ \\
\hline
\end{tabular}

8. Originator Remarks:

This document is being released into the supporting document system for retrievability purposes.
3. From: (originating Organization) Data Development and Interpretation

6. Design Authority/ Design Agent/Cog. Engr.:

$$
\text { S. G. McKinney }
$$

4. Related EDT No.: $N / A$

7. Purchase Order No.:

$N / A$

11. Receiver Remarks: 11A. Design Baseline Document? [] Yes $[X]$ No For release.

Nons

9. Equip./Component No.: $\mathrm{N} / \mathrm{A}$

10. System/Bldg./Facility: 241-AW-104

12. Major Assm. Dwg. No.: $\mathrm{N} / \mathrm{A}$

13. Permit/Permit Application No.: $\mathrm{N} / \mathrm{A}$

14. Required Response Date: $05 / 02 / 00$

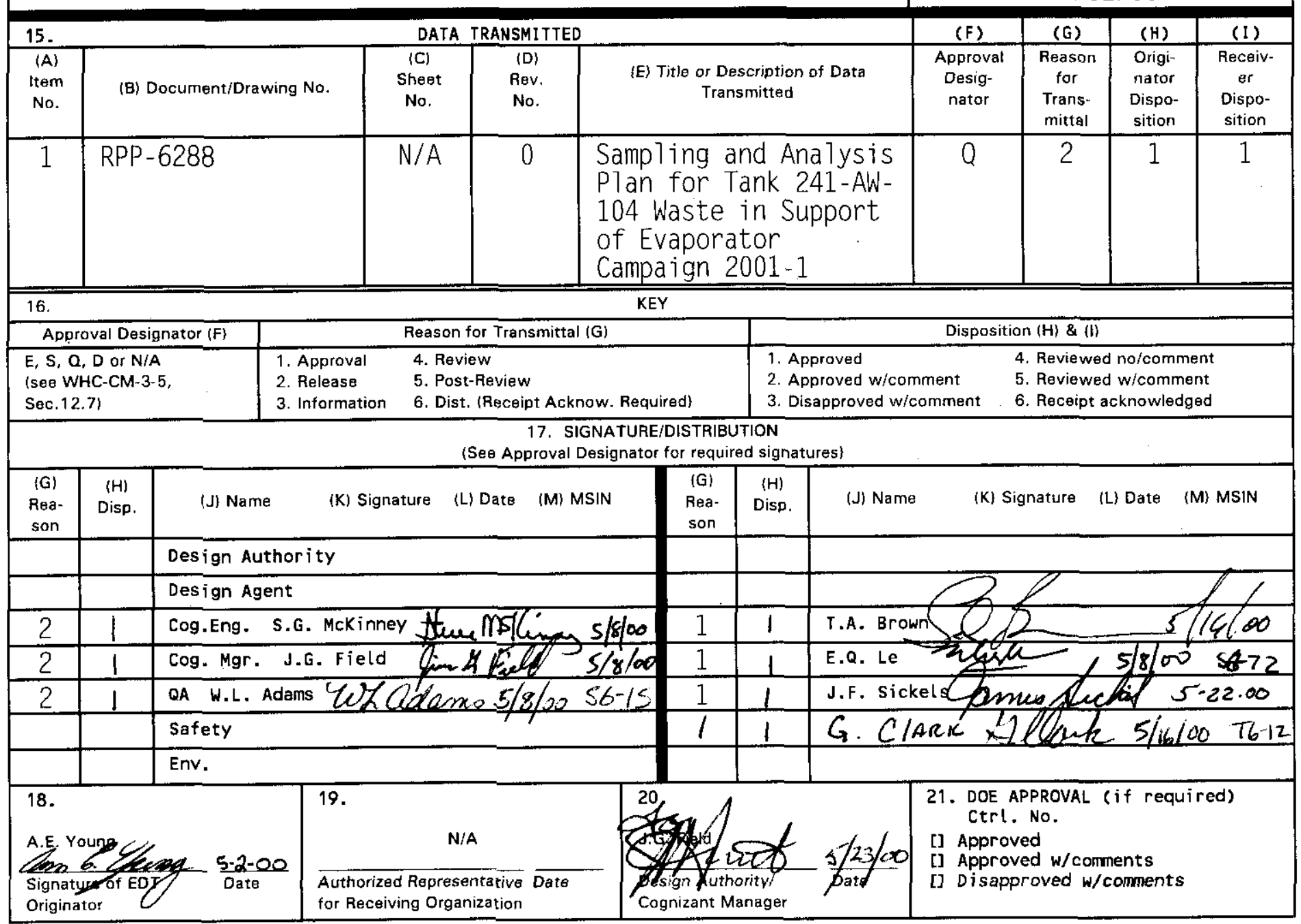

BD-7400-172-2(05/96) GEF097 


\title{
Sampling and Analysis Plan for Tank 241-AW-104 Waste in Support of Evaporator Campaign 2001-1
}

\author{
S. G. McKinney \\ CH2M HILL Hanford Group. Inc., Richland. WA 99352 \\ U.S. Department of Energy Contract DE-AC06-96RL13200

$\begin{array}{lll}\text { EDT/ECN: } & \text { EDT-628390 } & \text { UC: } 2070 \\ \text { Org Code: } & 74 B 20 & \text { CACN/COA: 102289/ES12 } \\ \text { B\&R Code: } & \text { EW } 3120074 & \text { Tota7 Pages: 20 } 21 \\ & & \end{array}$

Key Words: Sampling and Analysis Plan, Sampling. Analysis, Plan, Tank 241-AW-104, 241-AW-104. AW-104, Waste, Evaporator, Campaign 2001-1

Abstract: N/A

TRADEMARK DISCLAIMER. Reference herein to any specific commercial product, process, or service by trade name, trademark, manufacturer, or otherwise, does not necessarily constitute or imply its endorsement, recommendation, or favoring by the United States Government or any agency thereof or its contractors or subcontractors.

Printed in the United States of America. To obtain copies of this document, contact: Document Control Services, P.O. Box 950, Mailstop H6-08, Richland WA 99352, Phone (509) 372-2420;

Fax (509) 376-4989.
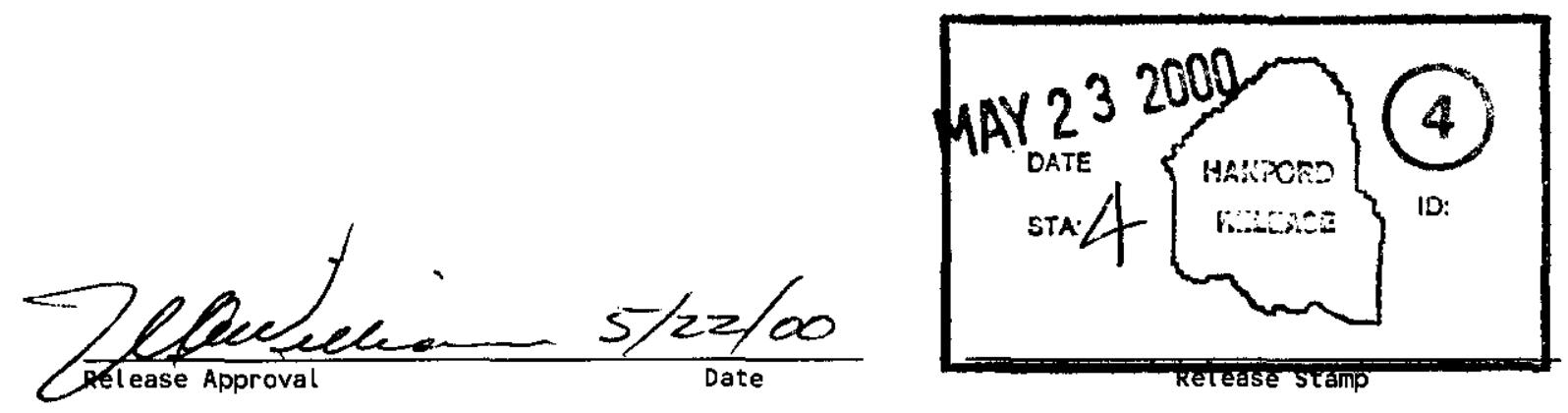

\section{Approved for Public Release}


RPP-6288

Revision 0

SAMPLING AND ANALYSIS PLAN FOR TANK 241-AW-104 WASTE IN SUPPORT OF EVAPORATOR CAMPAIGN 2001-1

S. G. McKinney

CH2M HILL Hanford Group, Inc.

Date Published

April 2000

Prepared for the U.S. Department of Energy

Office of River Protection 


\section{TABLE OF CONTENTS}

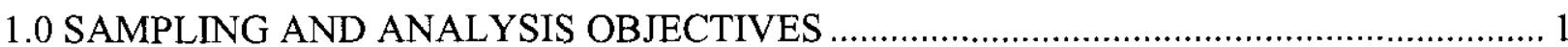

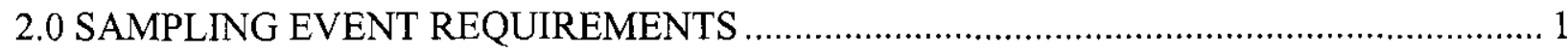

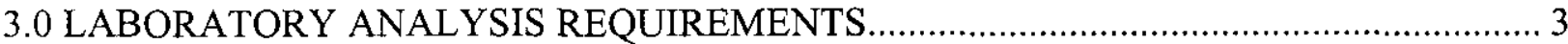

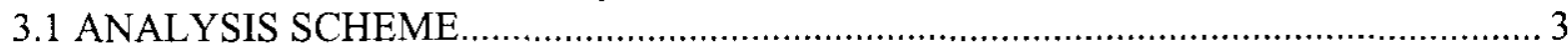

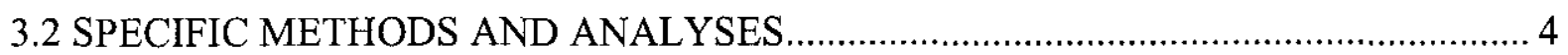

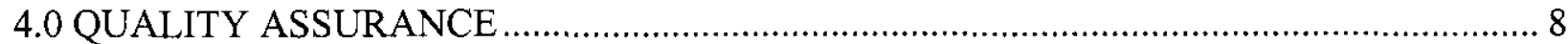

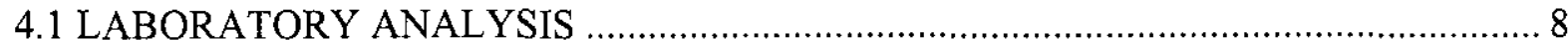

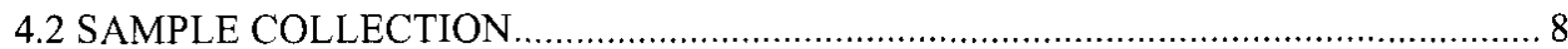

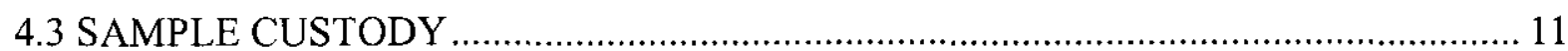

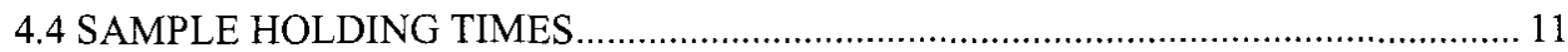

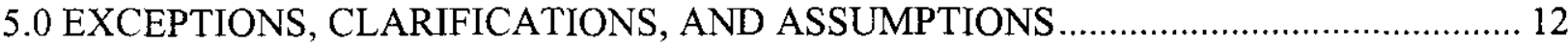

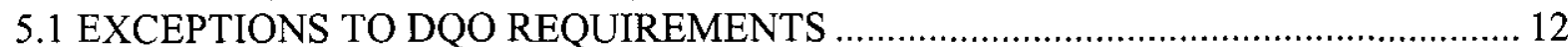

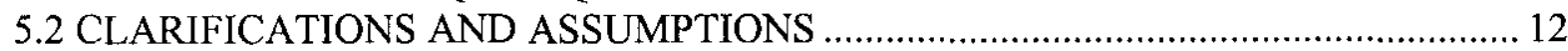

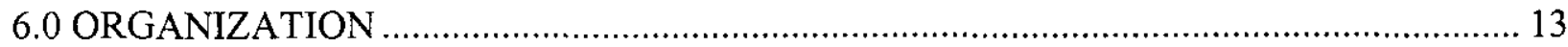

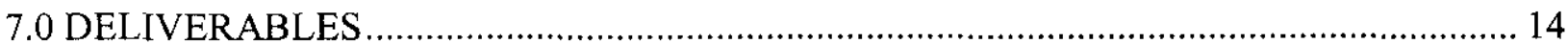

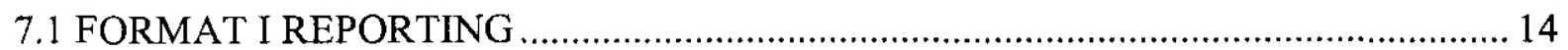

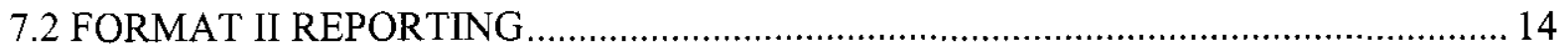

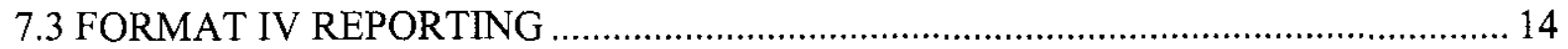

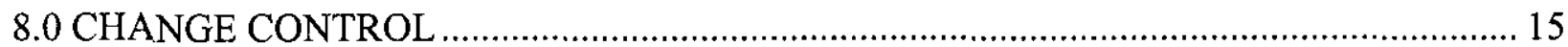

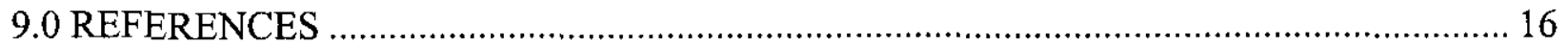

\section{LIST OF TABLES}

Table 2-1. Sampling Scheme for Tank 241-AW-104 Waste ............................................. 3

Table 3-1. Analytical Requirements for Tank 241-AW-104 Grab Samples ............................. 5

Table 4-1. QC Precision and Accuracy Requirements for the Analyses .............................. 9

Table 6-1. Tank 241-AW-104 Project Key Personnel........................................................ 13 
RPP-6288 Rev. 0

\section{LIST OF ABBREVIATIONS}

$\begin{array}{ll}\text { cal/g } & \text { calories per gram } \\ \text { CHG } & \text { CH2M HILL Hanford Group, Incorporated } \\ \text { CPO } & \text { Characterization Project Operations } \\ \text { DOE } & \text { U.S. Department of Energy } \\ \text { DQO } & \text { data quality objective } \\ \text { EPA } & \text { U.S. Environmental Protection Agency } \\ \text { FH } & \text { Fluor Hanford } \\ \text { gal } & \text { gallon } \\ \text { in. } & \text { inches } \\ \text { JCS } & \text { Job Control System } \\ \text { J/g } & \text { Joules per gram } \\ \text { LFL } & \text { lower flammability limit } \\ \text { LIMS } & \text { Laboratory Information Management System } \\ \text { mL } & \text { milliliter } \\ \text { msd } & \text { matrix spike duplicate } \\ \text { QA } & \text { quality assurance } \\ \text { QC } & \text { quality control } \\ \text { RPP } & \text { River Protection Project } \\ \text { SOW } & \text { statement-of-work } \\ \text { SVOA } & \text { semi-volatile organic analysis } \\ \text { TSAP } & \text { Tank Sampling and Analysis Plan } \\ \text { VOA } & \text { volatile organic analysis } \\ \text { WSCF } & \text { Waste Sampling and Characterization Facility laboratory } \\ \text { \% } & \text { percent }\end{array}$


RPP-6288 Rev. 0

\subsection{SAMPLING AND ANALYSIS OBJECTIVES}

This Tank Sampling and Analysis Plan (TSAP) identifies sample collection, laboratory analysis, quality assurance/quality control (QA/QC), and reporting objectives for the characterization of tank 241-AW-104 waste. Technical bases for these objectives are specified in the 242-A Evaporator Data Quality Objectives (Bowman 2000a and Von Bargen 1998), 242-A Evaporator Quality Assurance Project Plan (Bowman 1998 and Bowman 2000b), Tank 241-AW-104 Sampling Requirements in Support of Evaporator Campaign 2000-1 (Le 2000). Characterization results will be used to support the evaporator campaign currently planned for early fiscal year 2001. No other needs (or issues) requiring data for this tank waste apply to this sampling event.

\subsection{SAMPLING EVENT REQUIREMENTS}

Tank 241-AW-104 currently contains 820,000 gallons of dilute non-complexed supernate, 50,000 gallons of PL2 sludge, and 121,000 gallons of SMMA2 saltcake. The supernate waste will be processed in the 242-A Evaporator for volume reduction. Grab samples will be obtained in preparation for the evaporator campaign.

Field sampling shall be performed per the Plant Operating Procedure (POP) TO-080-403, "Supernatant or Sludge Sampling of Waste Storage Tanks." The overall sampling scheme is summarized in Table 2-1 and is further described below.

Prior to grab sampling, the dome space (below the riser) shall be measured for the presence of flammable gases. The measurement shall be taken from within the dome space and the data reported as a percentage of the lower flammability limit (LFL). The results shall be transmitted to the tank coordinator within ten working days of the sampling event (Schreiber 1998). If the dome space measurements were above 25 percent of the LFL, the Safety Issues Resolution group will determine the need for and frequency of further vapor sampling. Such additional vapor sampling is not within the scope of this TSAP.

Twelve 120-mL grab samples will be taken at three sub-surface locations. At each sub-surface location, four $120-\mathrm{mL}$ samples shall be taken: one for semi-volatile organic analysis (SVOA), one for volatile organic analysis (VOA), one for boil down and mixing study, and one for inorganic/radiological analysis. The location of each grab sample (in terms of riser number, cable length from the top of the riser, and elevation from the tank bottom) is specified in Table 21 .

In addition, four field blanks and two trip blanks will be used during the sampling event. The field blanks will consist of four 120-mL bottles: one for SVOA, one for VOA, and two for inorganic/radiological analyses. The trip blanks will consist of two $120-\mathrm{mL}$ bottles: one for VOA and another for SVOA. Blanks shall be filled at the laboratory with de-ionized, filtered (VOA free) water before they are brought to the field. The field blank check shall be performed 
by uncapping and lowering the appropriate bottles part way into a tank riser. The Characterization Project Operations (CPO) person-in-charge will verify field preparation and shipment of blanks to the laboratories.

Amber-colored, 120-mL pre-cleaned bottles that have been certified per the U.S. Environmental Protection Agency (EPA) Level 1 Procedure B shall be used for all samples and blanks taken for VOA. These bottles shall be sealed with septum caps. Amber-colored, 120-mL bottles, precleaned per EPA Level 1 Procedure A shall be used for the other samples and blanks. These bottles shall be sealed with Teflon caps. A summary of the analysis type, sample type, bottle lid type, and sample location (suggested riser number, elevation from the bottom of tank, and cable length) is provided in Table 2-1. Identification numbers unique to the individual samples are also included. Riser 3 is an approved alternate riser which may be used at the discretion of the CPO person-in-charge.

If quality-affecting changes to the sampling requirements (e.g., sample riser or elevation) must be made, such changes must be recorded and approved by the tank cognizant engineer and tank coordinator before sampling. The information may be recorded on a permanent data sheet or directly in the sampling work package. 
Table 2-1. Sampling Scheme for Tank 241-AW-104 Waste

\begin{tabular}{|c|c|c|c|c|c|}
\hline $\begin{array}{l}\text { Sample } \\
\text { Number }\end{array}$ & Analysis $^{1}$ & $\begin{array}{c}\text { Sample Type } \\
\text { Bottle Lid Type }^{2}\end{array}$ & $\begin{array}{c}\text { Riser } \\
\text { Number }\end{array}$ & $\begin{array}{c}\text { Cable } \\
\text { Length }^{3} \\
\end{array}$ & $\begin{array}{c}\text { Sample } \\
\text { Elev. }\end{array}$ \\
\hline $4 \mathrm{AW}-00-\mathrm{OB} 1$ & Organic/VOA & Field Blank, S & \multirow{4}{*}{$\begin{array}{c}\text { Riser } \\
020\end{array}$} & \multirow{4}{*}{$\begin{array}{c}222 \text { in. } \\
(18 \mathrm{ft} .6 \text { in. })\end{array}$} & \multirow{4}{*}{$\begin{array}{l}444 \text { in. } \\
(37 \mathrm{ft} .)\end{array}$} \\
\hline $4 \mathrm{AW}-00-0 \mathrm{~B} 2$ & Organic/SVOA & Field Blank, T & & & \\
\hline $4 \mathrm{AW}-00-1 \mathrm{~B} 1$ & Inorg/Rad & Field Blank, T & & & \\
\hline $4 \mathrm{AW}-00-1 \mathrm{~B} 2$ & Inorg/Rad & Field Blank, T & & & \\
\hline $4 \mathrm{AW}-00-1$ & Visual, TOC & Surface, $\mathrm{T}$ & $\begin{array}{c}\text { Riser- } \\
020\end{array}$ & $\begin{array}{c}260 \text { in. } \\
(21 \mathrm{ft} .8 \mathrm{in} .)\end{array}$ & $\begin{array}{c}406 \text { in. }^{5} \\
(33 \mathrm{ft} .10 \mathrm{in} .)\end{array}$ \\
\hline $4 \mathrm{AW}-00-2 \mathrm{~A}$ & Organic/VOA & Supernate, $S$ & \multirow{4}{*}{$\begin{array}{c}\text { Riser } \\
020\end{array}$} & \multirow{4}{*}{$\begin{array}{c}426 \text { in. } \\
\text { (35 ft. } 6 \text { in.) }\end{array}$} & \multirow{4}{*}{$\begin{array}{l}240 \mathrm{in} . \\
(20 \mathrm{ft} .)\end{array}$} \\
\hline $4 \mathrm{AW}-00-2 \mathrm{~B}$ & Organic/SVOA & Supernate, $\mathrm{T}$ & & & \\
\hline $4 \mathrm{AW}-00-2 \mathrm{C}$ & Inorg/Rad & Supernate, $\mathrm{T}$ & & & \\
\hline $4 \mathrm{AW}-00-2 \mathrm{D}$ & Mixing/Boildown & Supernate, $\mathrm{T}$ & & & \\
\hline $4 \mathrm{AW}-00-3 \mathrm{~A}$ & Organic/VOA & Supernate, S & \multirow{4}{*}{$\begin{array}{c}\text { Riser } \\
014\end{array}$} & \multirow{4}{*}{$\begin{array}{c}342 \text { in. } \\
\text { (28 ft. }-6 \text { in.) }\end{array}$} & \multirow{4}{*}{$\begin{array}{l}324 \mathrm{in} . \\
(27 \mathrm{ft})\end{array}$} \\
\hline $4 \mathrm{AW}-00-3 \mathrm{~B}$ & Organic/SVOA & Supernate, $\mathrm{T}$ & & & \\
\hline $4 \mathrm{AW}-00-3 \mathrm{C}$ & Inorg/Rad & Supernate, $\mathrm{T}$ & & & \\
\hline 4AW-00-3D & Mixing/Boildown & Supernate, T & & & \\
\hline $4 \mathrm{AW}-00-4 \mathrm{~A}$ & Organic/VOA & Supernate, $S$ & \multirow{4}{*}{$\begin{array}{c}\text { Riser } \\
014\end{array}$} & \multirow{4}{*}{$\begin{array}{c}502 \text { in. } \\
\text { (41 ft. } 10 \text { in.) }\end{array}$} & \multirow{4}{*}{$\begin{array}{c}164 \mathrm{in.} \\
\text { (13 ft. } 8 \text { in.) }\end{array}$} \\
\hline $4 \mathrm{AW}-00-4 \mathrm{~B}$ & Organic/SVOA & Supernate, $\mathrm{T}$ & & & \\
\hline $4 \mathrm{AW}-00-4 \mathrm{C}$ & Inorg/Rad & Supernate, $\mathrm{T}$ & & & \\
\hline $4 \mathrm{AW}-00-4 \mathrm{D}$ & Mixing/Boildown & Supernate, $\mathrm{T}$ & & & \\
\hline $4 \mathrm{AW}-00-\mathrm{TB} 1$ & Organic/VOA & Trip Blank, S & \multirow{2}{*}{ N/A } & \multirow{2}{*}{ N/A } & \multirow{2}{*}{ N/A } \\
\hline 4AW-00-TB2 & Organic/SVOA & Trip Blank, $T$ & & & \\
\hline
\end{tabular}

'Analysis type: Inorg = inorganic; $\mathrm{Rad}=$ radiological,

${ }^{2}$ Bottle lid type: $\mathrm{T}=$ Teflon Cap; $\mathrm{S}=$ Septum Cap (with lined septum)

${ }^{3}$ Cable Length is defined as the distance from the top of the tank riser to the mouth of the sample

${ }^{4}$ Sample elevation is defined as the distance from the bottom of the tank to the mouth of the sample bottle. If a sample cannot be obtained at the depth specified, the sampling assembly should be raised or lowered as necessary and the actual depth recorded.

${ }^{5}$ Prior to sampling, a zipcord or local measuring device reading shall be taken to determine the exact depth of the surface liquid level. Surface sample will be taken at one inch below this depth.

${ }^{6}$ Shipping information: Supernate radionuclides present in the highest concentration are ${ }^{137} \mathrm{Cs}$ and ${ }^{90} \mathrm{Sr}$. TBq content per $120-\mathrm{mL}$ bottle: $2.8 \mathrm{E}-04 \mathrm{TBq}$. TYPE A.

$\mathrm{N} / \mathrm{A}=$ not applicable

\subsection{LABORATORY ANALYSIS REQUIREMENTS}

\subsection{ANALYSIS SCHEME}

The following analyses will be performed to satisfy the data requirements as specified in the 242-A Evaporator and Compatibility Data Quality Objectives: 
- For all waste samples, observe and report any immiscible organic layer. Retain the immiscible material in a separate jar.

- Perform total organic carbon (TOC) analysis for the surface sample.

- Perform the following analyses for samples at each sub-surface location:

Samples for SVOA, VOA, inorganic/radiological analysis - Perform analyses as listed in Table 3-1.

Sample for boildown and mixing study - Archive the sample and wait for a letter-ofinstruction from the Evaporator Program.

- Perform the SVOA, VOA, inorganic, and radiological analyses as listed in Table 3-1 for the appropriate field blanks. However, $\mathrm{pH}$, differential scanning calorimetry (DSC), specific gravity $(\mathrm{SpG}), \%$ solids, and observation of appearance will not be performed.

- Perform SVOA and VOA on contents of the appropriate trip blanks.

- Retain $40 \mathrm{~mL}$ of waste from each sample for archive.

If the amount of material in a sample is insufficient to perform the requested analyses and retain $40 \mathrm{~mL}$ of waste for archive, the performing laboratory shall notify the tank coordinator within one working day. Direction for analyses of such samples will be provided to the laboratory. All analyses prescribed by this TSAP but not performed shall be documented and justified in the data report.

It is anticipated that the 222-S Laboratory will perform most of the analyses. If necessary, the laboratory may sub-contract certain analyses to another qualified laboratory. The sub-contracted laboratory shall meet all QA/QC requirements in this TSAP. The 222-S Laboratory will prepare a statement-of-work (SOW) authorizing the sub-contracted laboratory to perform the analyses. The SOW shall be reviewed and approved by River Protection Project (RPP) Process Engineering and Quality Assurance prior to commencement of laboratory analysis.

\subsection{SPECIFIC METHODS AND ANALYSES}

The requested analyses and laboratory procedures shown in Table 3-1 are based on the 242-A Evaporator Data Quality Objectives. Sample preparation procedures that may be used at the 222-S Laboratory are LA-549-141 for fusion digestion, LA-505-159 or LA-505-163 for acid digestion of samples, and LA-504-101 for water leach of solids. Analytical procedures that may be used by the sub-contracted laboratory will be specified in the SOW. 


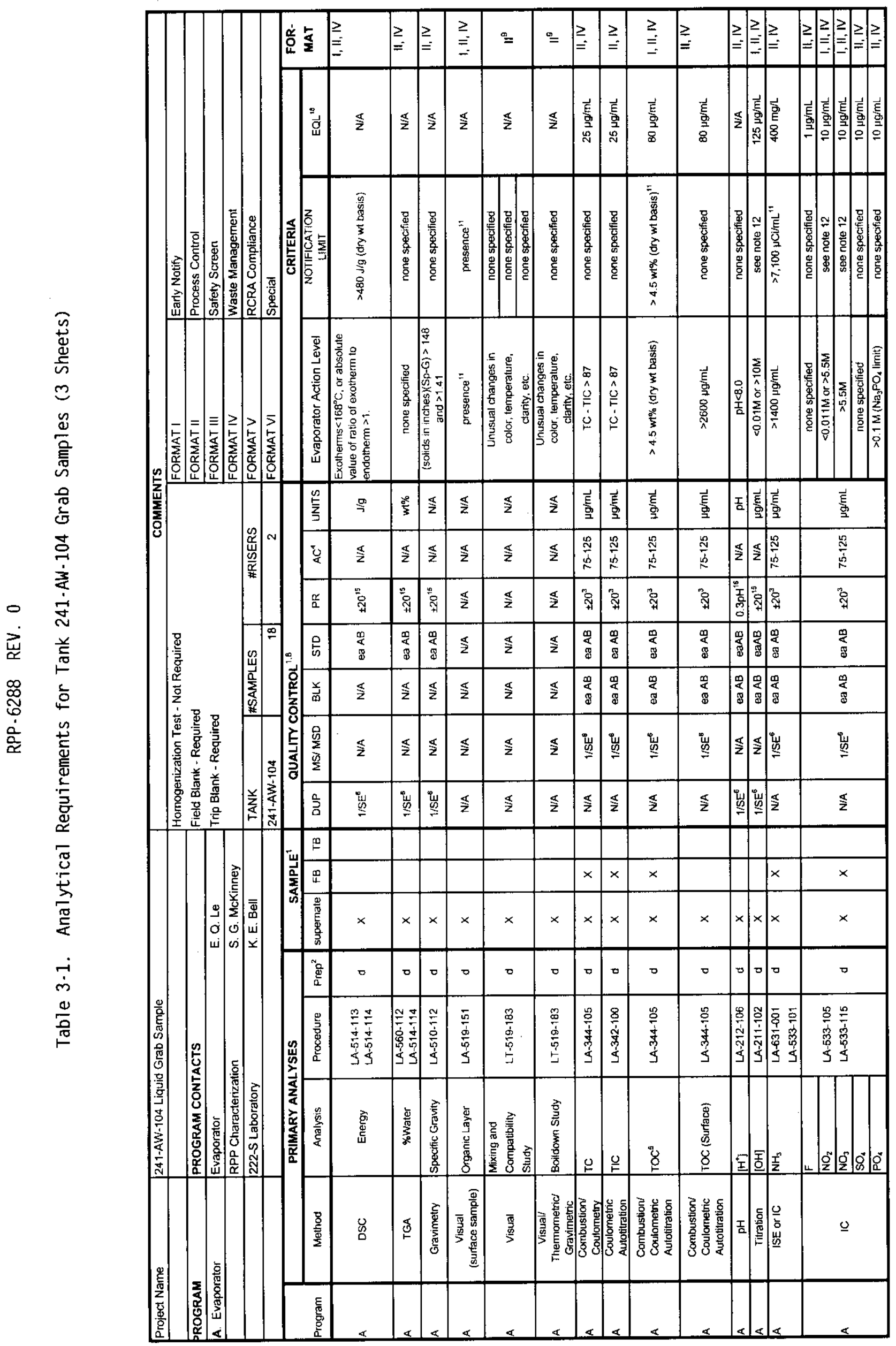




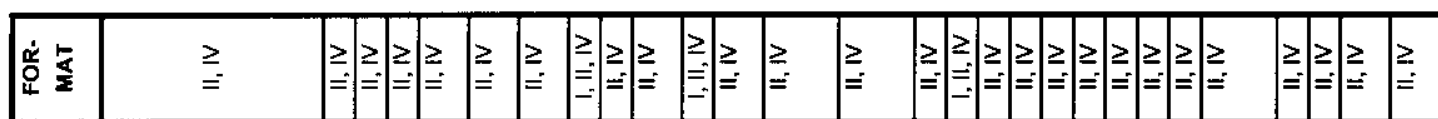

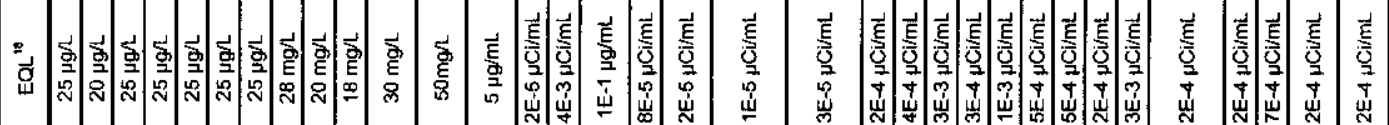

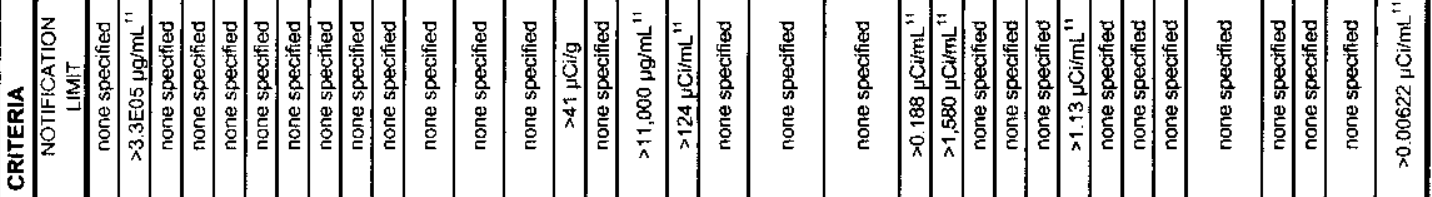

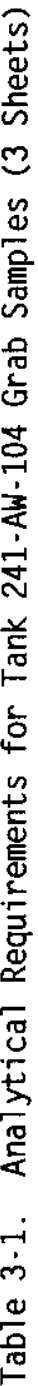

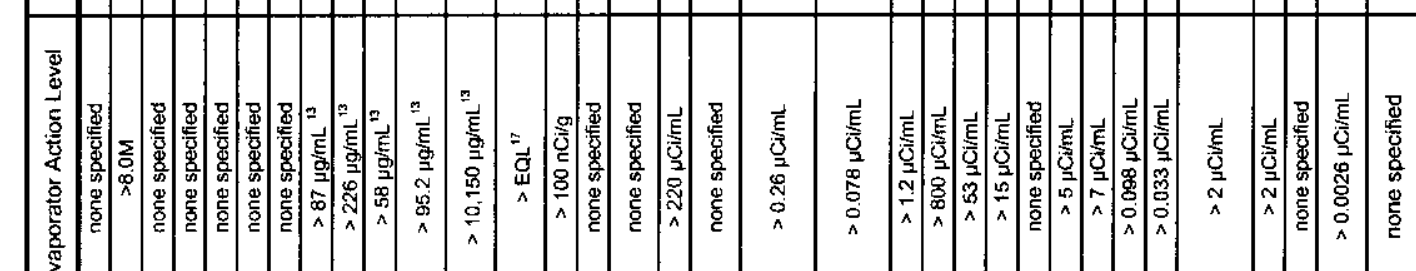
离

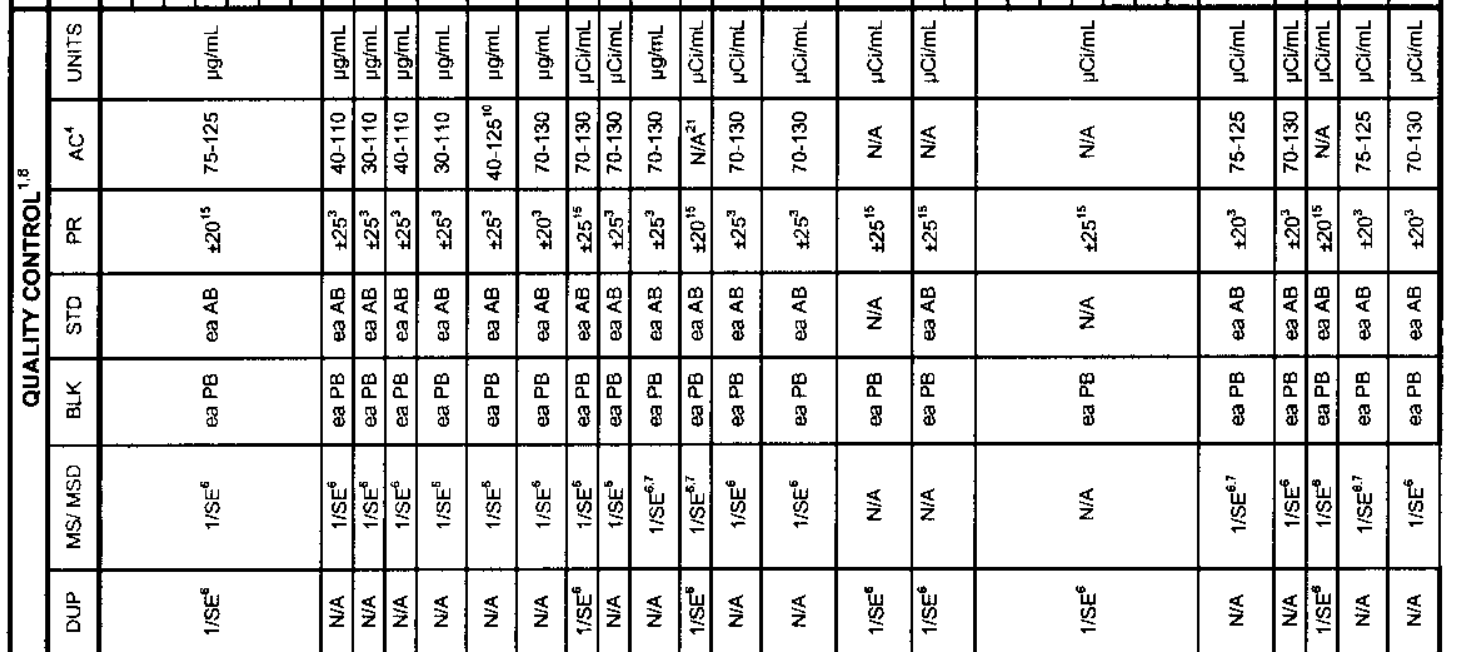

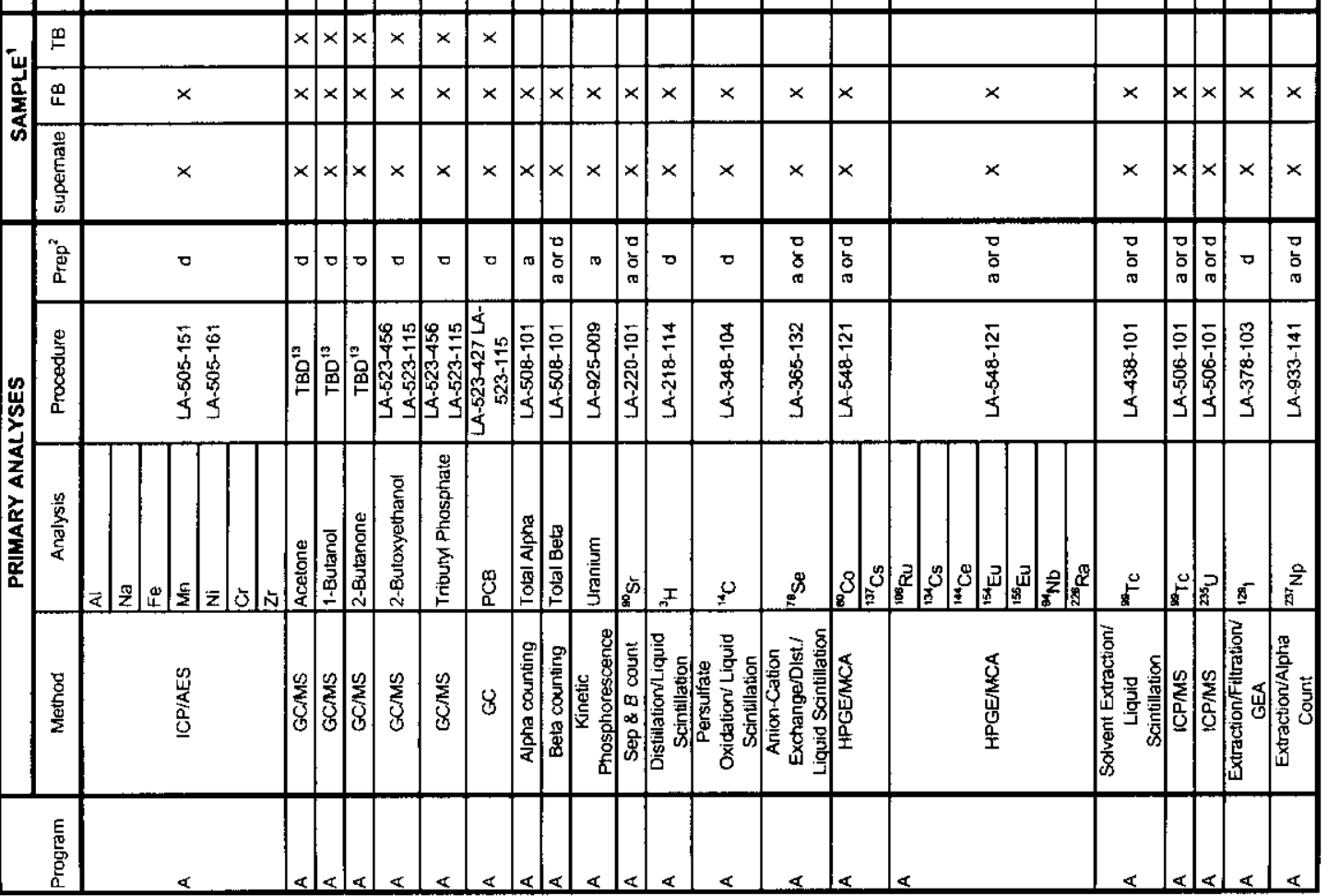




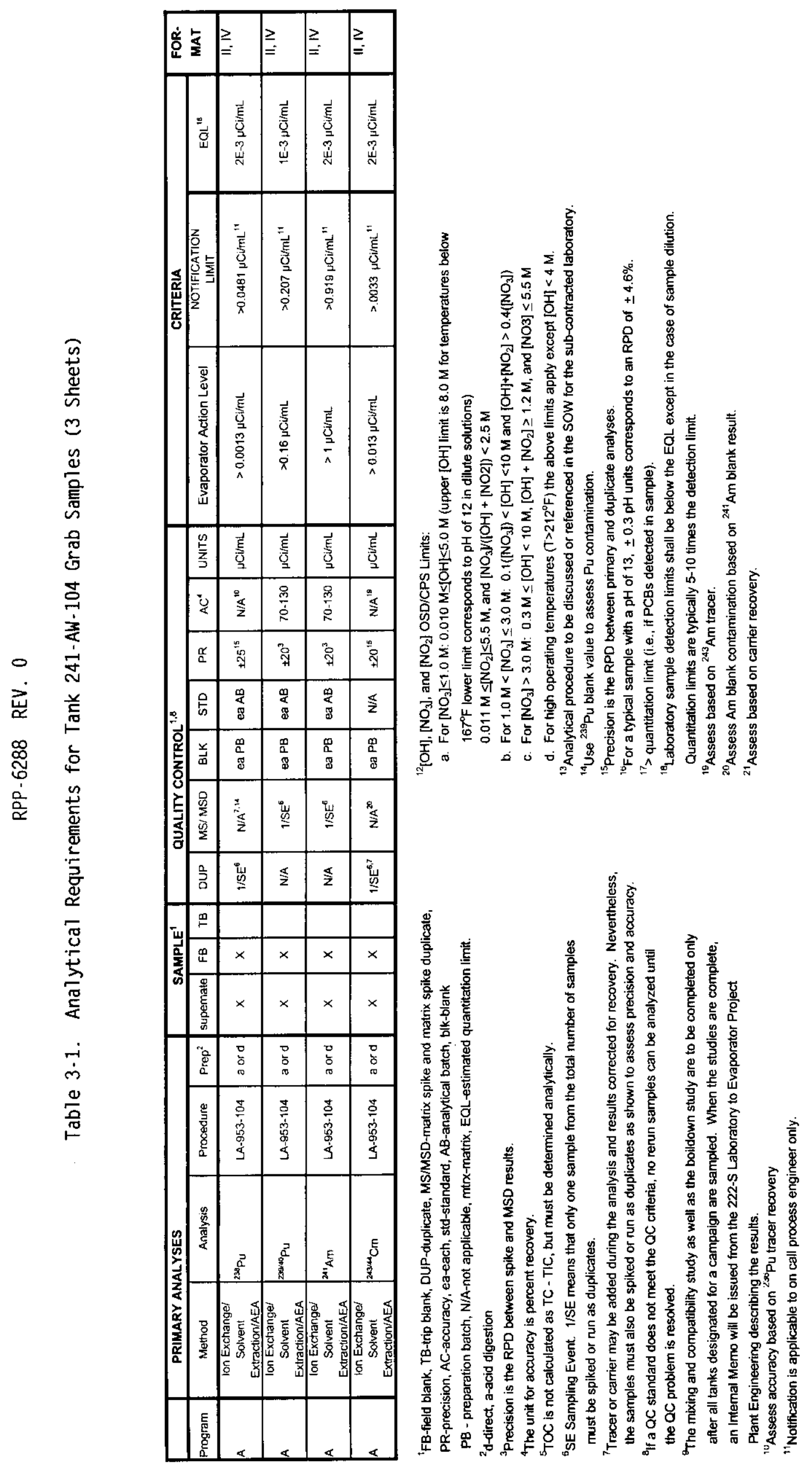


RPP-6288 Rev. 0

\subsection{QUALITY ASSURANCE}

Overall quality policies for conducting Characterization Project sampling and analysis are described in Tank Waste Remediation System Characterization Project, Quality Policies (Board 1998). Specific quality assurance requirements for laboratory analysis, sample collection, and sample traceability are provided in this section. All sampling and analysis activities shall be performed in accordance with the requirements in this TSAP and the appropriate references. Data resulting from activities and conditions that do not conform to requirements specified in this TSAP or references herein shall be controlled to prevent inadvertent use or documented with appropriate cautions. Nonconforming sampling and analysis processes and information shall be identified, controlled, reported, and dispositioned as required by Nonconforming Item Reporting and Control (CHG 1999).

\subsection{LABORATORY ANALYSIS}

Laboratories performing analyses in support of this TSAP shall have approved and implemented quality assurance project plans. These QA plans shall meet the Hanford Analytical Services Quality Assurance Requirements Document (DOE 1998) minimum requirements as the baseline for laboratory quality systems. The 222-S Laboratory Quality Assurance Plan (Markel 1999) and the Waste Sampling and Characterization Facility Quality Assurance Program Plan (Meznarich 1999) specify the requirements for assuring the quality of sample analysis conducted at the 222-S and Waste Sampling and Characterization Laboratory (WSCF). Appropriate QA plan(s) for analyses to be performed at the sub-contracted laboratory will be discussed or referenced in the laboratory SOW.

Analytical QC requirements (duplicates, spikes, blanks, laboratory control samples) are identified in Table 4-1. The laboratories shall use calibration and calibration check standards appropriate for the analytical instrumentation being used (see DOE 1998 for definitions of QC samples and standards). The criteria presented are goals for demonstrating reliable method performance. It is understood that the laboratories will follow established internal protocols for addressing QC failures. If sample QC failures occur or if some analyses cannot be performed (e.g., because of insufficient sample), analysts shall consult with the tank coordinator to determine the proper action. The performing laboratory should provide a suggested course of action at that time. All sample QC failures and limitations on the associated data shall be discussed in the narrative of the data report. Proper notification of all data not meeting QC requirements shall be included with the data.

\subsection{SAMPLE COLLECTION}

Before sampling can be performed on a tank, available risers must be identified for use in the sampling event. The selected risers must be inspected and prepared for sampling. Safety hazards must be identified and special precautions must be taken if needed. If deemed necessary 
by the sampling cognizant engineers and tank coordinator, video surveillance will be performed to identify any potential problems that may occur during the sampling event.

Samples shall be taken and shipped to the 222-S Laboratory by CPO in accordance with the Job Control System (JCS) work package. Each sample should be delivered to the laboratory within three days of sampling. Also, CPO will verbally notify the 222-S Laboratory at least 24 hours in advance of an expected shipment.

Table 4-1. QC Precision and Accuracy Requirements for the Analyses (2 Sheets)

\begin{tabular}{|c|c|c|c|c|}
\hline Analysis/Method & $\begin{array}{c}\text { Duplicate } \\
\text { Criteria (RPD) }\end{array}$ & $\begin{array}{l}\text { Spike Criteria } \\
(\% \text { recovery) }\end{array}$ & $\begin{array}{c}\text { Preparation } \\
\text { Blank Criteria }^{3}\end{array}$ & $\begin{array}{c}\text { LCS Criteria } \\
(\% \text { recovery })^{4}\end{array}$ \\
\hline DSC & $\leq 20$ & N/A & N/A & $80-120$ \\
\hline $\mathrm{TGA}$ & $\leq 20$ & N/A & N/A & $80-120$ \\
\hline $\mathrm{OH}$ & $\leq 20$ & N/A & $<\mathrm{EQL}$ & $80-120$ \\
\hline $\mathrm{NH}_{3}$ & $\leq 20$ & $75-125$ & $<\mathrm{EQL}$ & $80-120$ \\
\hline Specific gravity & $\leq 20$ & N/A & N/A & $80-120$ \\
\hline ICP/AES & $\leq 20$ & $75-125$ & $<\mathrm{EQL}$ & $80-120$ \\
\hline IC & $\leq 20$ & $75-125$ & $<\mathrm{EQL}$ & $80-120$ \\
\hline GEA & $\leq 25$ & N/A & $<\mathrm{MDA}$ & $80-120$ \\
\hline${ }^{90} \mathrm{Sr}$ & $\leq 20$ & $N / A^{5}$ & $<\mathrm{MDA}$ & $75-125$ \\
\hline${ }^{79} \mathrm{Se}$ & $\leq 25$ & $N / A^{5}$ & $<\mathrm{MDA}$ & N/A \\
\hline${ }^{3} \mathrm{H}$ & $\leq 25$ & $70-130$ & $<\mathrm{MDA}$ & $80-120$ \\
\hline${ }^{14} \mathrm{C}$ & $\leq 25$ & $70-130$ & $<\mathrm{MDA}$ & $80-120$ \\
\hline${ }^{99} \mathrm{Tc}$ & $\leq 20$ & $75-125$ & $<\mathrm{MDA}$ & $80-120$ \\
\hline${ }^{129} \mathrm{I}$ & $\leq 20$ & $75-125$ & $<\mathrm{MDA}$ & $80-120$ \\
\hline${ }^{235} \mathrm{U}$ & $\leq 20$ & $75-125$ & $<\mathrm{EQL}$ & $80-120$ \\
\hline${ }^{241} \mathrm{Am}$ & $\leq 20$ & $70-130$ & $<\mathrm{MDA}$ & $80-120$ \\
\hline${ }^{237} \mathrm{~Np}$ & $\leq 20$ & $70-130$ & $<\mathrm{MDA}$ & $90-110$ \\
\hline${ }^{239 / 240} \mathrm{Pu}$ & $\leq 20$ & $70-130$ & $<\mathrm{MDA}$ & $80-120$ \\
\hline${ }^{238} \mathrm{Pu}$ & $\leq 25$ & $\mathrm{~N} / \mathrm{A}^{5}$ & $<\mathrm{MDA}$ & $80-120$ \\
\hline${ }^{243 / 244} \mathrm{Cm}$ & $\leq 20$ & $N / A^{5}$ & $<\mathrm{MDA}$ & N/A \\
\hline
\end{tabular}


RPP-6288 Rev. 0

Table 4-1. QC Precision and Accuracy Requirements for the Analyses (2 Sheets)

\begin{tabular}{|l|c|c|c|c|}
\hline Analysis/Method & $\begin{array}{c}\text { Duplicate } \\
\text { Criteria (RPD) }\end{array}$ & $\begin{array}{c}\text { Spike Criteria } \\
\text { (\% recovery) }\end{array}$ & $\begin{array}{c}\text { Preparation } \\
\text { Blank Criteria }^{3}\end{array}$ & $\begin{array}{c}\text { LCS Criteria } \\
\text { (\% recovery) }\end{array}$ \\
\hline AT & $\leq 25$ & $70-130$ & $<\mathrm{MDA}$ & $70-130$ \\
\hline TB & $\leq 25$ & $70-130$ & $<\mathrm{MDA}$ & $70-130$ \\
\hline Total U & $\leq 20$ & $70-125$ & $<\mathrm{EQL}$ & $80-120$ \\
\hline TIC/TOC/TC & $\leq 20$ & $75-125$ & $<\mathrm{EQL}$ & $80-120$ \\
\hline Acetone & $\leq 25$ & $40-110$ & $<\mathrm{EQL}$ & $70-130$ \\
\hline 1-Butanol & $\leq 25$ & $30-110$ & $<\mathrm{EQL}$ & $70-130$ \\
\hline 2-Butoxyethanol & $\leq 25$ & $30-110$ & $<\mathrm{EQL}$ & $70-130$ \\
\hline $\begin{array}{l}\text { 2-Butanone } \\
\text { (MEK) }\end{array}$ & $\leq 25$ & $40-110$ & $<\mathrm{EQL}$ & $70-130$ \\
\hline Tributyl phosphate & $\leq 20$ & $70-130$ & $<\mathrm{EQL}$ & $70-130$ \\
\hline $\begin{array}{l}\text { Polychlorinated } \\
\text { biphenyls (PCB) }\end{array}$ & $\leq 0.3 \mathrm{pH}$ unit & N/A & N/A & $\pm 0.1 \mathrm{pH}$ unit \\
\hline pH & $\leq 25$ & $<\mathrm{EQL}$ & $70-130$ \\
\hline
\end{tabular}

$\mathrm{N} / \mathrm{A} \quad=$ not applicable

AT $=$ total alpha

$\mathrm{DSC}=$ differential scanning calorimetry

MDA = minimum detectable activity

$\mathrm{EQL}=$ estimated quantitation limit

GEA = gamma energy analysis

IC = ion chromatography

$\mathrm{ICP} / \mathrm{AES}=$ inductively coupled plasma/atomic emission spectroscopy

LCS = laboratory control standard

$\mathrm{RPI}=$ relative percent difference

TB = total beta

$\mathrm{TC}=$ total carbon

TGA =thermogravimetric analysis

TIC = total inorganic carbon

$\mathrm{TOC}=$ total organic carbon

${ }^{1}$ For the calculation of the RPD, both the sample and duplicate results must exceed the EQL or MDA. Failures are permissible if the requirements in the QA section are followed.

${ }^{2}$ The criteria are recommended. Failures are permissible if the requirements in the QA section are followed.

${ }^{3}$ When a blank exceeds the EQL or MDA, sample results that exceed the contribution from the blank twenty-fold or more are reportable. The Blank value shall not exceed either 1) the EQL or MDA; 2) the lower of the

Evaporator Action Level or RPP Notification Limit; or 3) $5 \%$ of the mean sample concentration; or which ever is higher.

${ }^{4}$ For some analyses, this could be a method spike or a blank spike. Ranges are percent recovery of theoretical.

${ }^{5} \mathrm{~A}$ tracer or carrier may be substituted for the spike. 
RPP-6288 Rev. 0

Table 4-1. QC Precision and Accuracy Requirements for the Analyses (2 Sheets)

\begin{tabular}{|c|c|c|c|c|}
\hline Analysis/Method & $\begin{array}{c}\text { Duplicate } \\
\text { Criteria (RPD) }^{1}\end{array}$ & $\begin{array}{l}\text { Spike Criteria } \\
(\% \text { recovery })^{2}\end{array}$ & $\begin{array}{c}\text { Preparation } \\
\text { Blank Criteria }^{3}\end{array}$ & $\begin{array}{l}\text { LCS Criteria } \\
\text { (\% recovery) }\end{array}$ \\
\hline
\end{tabular}

\subsection{SAMPLE CUSTODY}

The sampling team shall initiate a chain-of-custody form as described in the work package. The identification number unique to each sample as assigned in this TSAP shall be recorded. Each sample shall be identified as a surface sample, sub-surface sample, or a trip/field blank. The location (riser and elevation) at which the sample was obtained shall be recorded. Also, pertinent sampling information (e.g., unusual waste characteristics or sampling problems) should be noted in the Comments section of the chain-of custody form.

Each sample will be shipped to the laboratories in a sample pig and sealed with a Waste Tank Sample Seal (see below). A chain-of-custody form shall accompany each sample. The receipt and control of samples in the 222-S Laboratory are described in laboratory procedure LO-090-101. Chain-of-custody requirements for samples to be analyzed at the sub-contracted laboratory will be addressed in the SOW.

\begin{tabular}{||l|l||}
\hline \multicolumn{2}{|c|}{ WASTE TANK SAMPLE SEAL } \\
\hline \hline Supervisor: & Sample No.: \\
\hline Date of Sampling: & Time of Sampling: \\
\hline Shipment No.: & Serial No.: \\
\hline
\end{tabular}

\subsection{SAMPLE HOLDING TIMES}

Sampling organizations and analytical laboratories shall strive to meet the holding times specified in SW-846, Test Methods for the Evaluation of Solid Waste, Physical/Chemical Methods (EPA 1986). However, it is recognized that high radioactivity and difficult sample matrices may require additional time to ship, prepare, and analyze the samples. Adherence to the holding times is not strictly required if it can be shown and documented that reasonable efforts were made to meet the requirements. All analytical data that exceed holding times shall be identified and discussed in the Format IV data package. 


\subsection{EXCEPTIONS, CLARIFICATIONS, AND ASSUMPTIONS}

\subsection{EXCEPTIONS TO DQO REQUIREMENTS}

The laboratory shall report all analytical results recovered from the inductively coupled plasma atomic emission spectroscopy (ICP/AES), gamma energy analysis (GEA), and ion chromatography (IC) analyses, even though only specific analytes are requested. These opportunistic results will be reported only if no additional preparatory work is required and the associated errors are documented (Kristofzski 1996). No reruns or additional analyses will be performed to improve recovery for analytes not specified in Table 3-1 unless formally requested by the tank coordinator.

$\mathrm{Pu}-241$ is specified in the DQO but an analytical method is not available. Pu-241 concentration will be estimated based on the amount of Pu-239 in the waste.

\subsection{CLARIFICATIONS AND ASSUMPTIONS}

The energy releases by an exothermic reaction (in cal/g or $\mathrm{J} / \mathrm{g}$ ) as determined by differential scanning calorimetry (DSC) must be converted to and reported on a dry weight basis. The average weight percent water for that sample as determined from thermogravimetric analysis (TGA) will be used per Equation 1 for this conversion.

$$
\text { Exotherm }(\text { dry wt })=\frac{[\text { exotherm }(\text { wet wt }) \times 100]}{100-(\% \text { water })}
$$

NOTE: A large error in the DSC value may result when converting samples containing greater than 90 percent water to a dry weight basis. However, this conversion is still required. 


\subsection{ORGANIZATION}

The organization and responsibility of key personnel involved with this characterization effort are shown in Table 6-1.

Table 6-1. Tank 241-AW-104 Project Key Personnel

\begin{tabular}{|l|l|l|}
\hline \multicolumn{1}{|c|}{ Responsibility } & \multicolumn{1}{|c|}{ Organization } & \multicolumn{1}{c|}{ Individual } \\
\hline $\begin{array}{l}\text { Manager, Data Development } \\
\text { and Integration }\end{array}$ & $\begin{array}{l}\text { River Protection Project (RPP) } \\
\text { Process Engineering (CHG) }\end{array}$ & J. G. Field, 376-3753 \\
\hline Tank Coordinator & RPP Process Engineering (CHG) & $\begin{array}{l}\text { S. G. McKinney, 372-1945 } \\
\text { (fax: 373-4641) }\end{array}$ \\
\hline $\begin{array}{l}\text { Double-Shell Tank Farms } \\
\text { Engineering point of contact }\end{array}$ & $\begin{array}{l}\text { Double-Shell Tank Farms: } \\
\text { Engineering (CHG) }\end{array}$ & T. M. Blaak, 373-3880 \\
\hline Evaporator point of contact & Environmental Compliance (FH) & E. Q. Le, 373-4214 \\
\hline $\begin{array}{l}\text { 222-S Laboratory point of } \\
\text { contact (day shift) }\end{array}$ & $\begin{array}{l}\text { Hanford Analytical Laboratory } \\
\text { Operations (FH) }\end{array}$ & K. E. Bell 372-2553 \\
\hline $\begin{array}{l}\text { 222-S Laboratory point of } \\
\text { contact (off hours) }\end{array}$ & Analytical Services (FH) & $\begin{array}{l}\text { 222-S Laboratory shift } \\
\text { manager, 373-2435 }\end{array}$ \\
\hline $\begin{array}{l}\text { Double-Shell Tank Farm } \\
\text { point of contact }\end{array}$ & Tank Farm Operations (CHG) & $\begin{array}{l}\text { Double-Shell Tank Farm } \\
\text { Operations shift manager, } \\
\text { 373-2689 }\end{array}$ \\
\hline $\begin{array}{l}\text { Field sampling point of } \\
\text { contact }\end{array}$ & $\begin{array}{l}\text { Characterization Project } \\
\text { Operations Field } \\
\text { Sampling(CHG) }\end{array}$ & J. F. Sickels, 372-0259 \\
\hline $\begin{array}{l}\text { Process Engineering Point of } \\
\text { Contact for Immediate } \\
\text { Notifications }\end{array}$ & RPP Process Engineering (CHG) & $\begin{array}{l}\text { On-Call Process Engineer } \\
\text { 539-2074 or 85-9654 (pager) }\end{array}$ \\
\hline
\end{tabular}




\subsection{DELIVERABLES}

All analyses of tank 241-AW-104 waste material shall be reported as Formats I, II, and/or IV as indicated in Table 3-1. Brief descriptions of these reporting formats are provided here. Additional information regarding reporting formats for analytical data is given in the Letter of Intent for River Protection Project (RPP) Characterization Program: Process Engineering, Hanford Analytical Services, Characterization Project Operations, and Quality Assurance (Thompson 2000).

\subsection{FORMAT I REPORTING}

This format requires immediate notification for certain analytes when the notification limits specified in Table 3-1 are exceeded. The performing laboratory shall report, via telephone, any results exceeding the corresponding limits to the appropriate Tank Farm Operations shift manager and/or the on-call process engineer as soon as the data are reviewed by a qualified scientist(s). Within one hour of this verbal notification, the laboratory shall provide electronic notification to the Tank Farm Operations shift manager, the RPP Process Engineering Data Assessment and Interpretation manager, and the tank coordinator. Additional analyses for verification purposes may be performed as directed by the tank coordinator in an engineering change notice to this TSAP or in a letter.

\subsection{FORMAT II REPORTING}

This format requires early transmittal of analytical results. The deliverables will consist of data tables from the Laboratory Information Management System (LIMS). It will be transmitted to the Evaporator Project and RPP Process Engineering via electronic mail or facsimile.

\subsection{FORMAT IV REPORTING}

This format requires a comprehensive report of analytical data. The report shall include results of the analyses required by the Evaporator Data Quality Objectives. All analytical data, including waste sample analyses, blank analyses, holding time checks, matrix spike duplicate (MSD) analyses, surrogate recoveries shall be verified by the laboratory prior to reporting. The data package will be provided to the Evaporator Project, RPP Process Engineering, the Tank Characterization and Safety Resource Center, and Tank Characterization Database representatives. Because of the urgency of obtaining results to support Evaporator Campaign 2000-1, the laboratory shall make every effort to complete the data package within 120 days of the sampling event.

In addition to this data package, the analytical results shall be entered into the Tank Characterization Database. The electronic data must be available for viewing by the Washington State Department of Ecology within 7 days of the release of the final report. The electronic 
version of the data package shall be in the standard electronic format specified in Lang et al. (1999).

\subsection{CHANGE CONTROL}

All significant changes to the sampling, analysis, or QA/QC requirements in this TSAP shall be documented by RPP Process Engineering in an engineering change notice or a letter. All such changes shall be clearly documented in the final data report. Minor changes may be documented by placing a notation in the appropriate permanent record (e. g., extrusion logbook or memorandum to file). The determination whether a change is significant or not shall be made by the tank coordinator. 


\subsection{REFERENCES}

Board, D. C., 1998, Tank Waste Remediation System, Characterization Project, Quality Policies, HNF-SD-WM-QAPP-025, Rev. 4, Lockheed Martin Hanford Corporation, Richland, Washington.

Bowman, M. W., 1998, 242-A Evaporator Data Quality Assurance Project Plan, HNF-SD-WMQAPP-009, Rev. 3, Waste Management Federal Services of Hanford, Richland, Washington.

Bowman, M. W., 2000a, ECN 653669, 242-A Evaporator Data Quality Objectives, HNF-SDWM-DQO-014, Rev. 2, Fluor Hanford Incorporated, Richland, Washington.

Bowman, M. W., 2000b, ECN 653670, 242-A Evaporator Data Quality Assurance Project Plan, HNF-SD-WM-QAPP-009, Rev. 3, Fluor Hanford Incorporated, Richland, Washington.

Brown, T. M., J. W. Hunt, and L. J. Fergestrom, 1998, Tank Characterization Technical Sampling Basis, HNF-SD-WM-TA-164, Rev. 4, Lockheed Martin Hanford Corporation, Richland, Washington.

CHG, 1999, Project Hanford Policy and Procedure System, Nonconforming Item Reporting and Control, (Section 3.0), RPP-PRO-298, Rev. 0, CH2M HILL Hanford Group, Inc., Richland, Washington.

DOE, 1998, Hanford Analytical Services Quality Assurance Requirements Document, DOE/RL-96-68, Rev. 2, U.S. Department of Energy, Richland Field Office, Richland, Washington.

EPA, 1986, Test Methods for the Evaluation of Solid Waste, Physical/Chemical Methods, SW846, $3^{\text {rd }}$ Edition, U. S. Environmental Protection Agency, Washington, D. C.

Fowler, K. D., 1999, Tank Farm Waste Compatibility Program, HNF-SD-WM-OCD-015, Rev. 2, U. S. Department of Energy, Richland, Washington.

Kristofzski, J. G., 1996, Directions for “Opportunistic Analysis", (internal memorandum 75310-96-168 to J. H. Baldwin et al., September 11), Westinghouse Hanford Company, Richland, Washington.

Lang, L. L., S. F. Bobrowski, and S. J. Harris, 1999, Standard Electronic Format Specification for Tank Characterization Data Loader, Version 3.0, HNF-3638, Rev. 1, prepared by Pacific Northwest Laboratory for Lockheed Martin Hanford Company, Richland, Washington. 
Le, E. Q., 2000, Tank 241-AW-104 Sampling Requirements in Support of Evaporator Campaign 2000-1, (memorandum FH-0002237 to S. G. McKinnet, April 20), Fluor Hanford, Richland, Washington.

Markel, L. P., 1999, 222-S Laboratory Quality Assurance Plan, HNF-SD-CP-QAPP-016, Rev. 3-C, Waste Management Federal Services of Hanford, Inc., Richland, Washington.

Meznarich, H. K., 1999, Waste Sampling and Characterization Facility Quality Assurance Program Plan, HNF-SD-CP-QAPP-017, Rev. 3, Waste Management, Inc. for Fluor Daniel Hanford, Inc., Richland, Washington.

Mulkey, C. H., M. Miller, and L. Jackson, 1999, Data Quality Objectives for Tank Farms Waste Compatibility Program, HNF-SD-WM-DQO-001, Rev. 3, Lockheed Martin Hanford Corp. for Fluor Daniel Hanford Inc., Richland, Washington.

Thompson, R. R., 2000, Letter of Intent for River Protection Project (RPP) Characterization Program: Process Engineering, Hanford Analytical Services, Characterization Project Operations, and Quality Assurance, RPP-5539, CH2M Hill Hanford Group, Inc., Rev. 0, Richland, Washington.

Von Bargen, B. H., 2000, 242-A Evaporator Data Quality Objectives, HNF-SD-WM-DQO-014, Rev. 2, Fluor Hanford Incorporated, Richland, Washington. 


\begin{tabular}{|c|c|c|c|c|c|}
\hline \multicolumn{6}{|c|}{ DISTRIBUTION SHEET } \\
\hline \multirow[b]{2}{*}{ Distribution } & \multirow{2}{*}{\multicolumn{3}{|c|}{ From }} & \multicolumn{2}{|l|}{ Page 1 of 1} \\
\hline & & & & \multicolumn{2}{|c|}{ Date $\quad 05 / 02 / 00$} \\
\hline \multicolumn{4}{|l|}{$\begin{array}{l}\text { Project Title/Work Order } \\
\text { RPP-6288 Rev } 0 \text { "Samnling an }\end{array}$} & \multicolumn{2}{|c|}{ EDT No. $\quad$ EDT-628390 } \\
\hline $\begin{array}{l}\text { RPP-6288, Rev. 0, "Sampling an } \\
104 \text { Waste in Support of Evapor }\end{array}$ & $\begin{array}{l}\text { Analysis Plan } \\
\text { or Campaign } 20\end{array}$ & $\begin{array}{l}\text { for Tank } \\
\text { b1-1" }\end{array}$ & 41-AW- & \multicolumn{2}{|c|}{ ECN No. N/A } \\
\hline Name & MSIN & $\begin{array}{l}\text { Text } \\
\text { With } \\
\text { A17 } \\
\text { Attach. }\end{array}$ & Text Only & $\begin{array}{l}\text { Attach./ } \\
\text { Appendix } \\
\text { Only }\end{array}$ & $\begin{array}{l}\text { EDT/ECN } \\
\text { Only }\end{array}$ \\
\hline $\begin{array}{l}\text { CH2M HILL Hanford Group, Inc. } \\
\text { W. L. Adams } \\
\text { T. M. Blaak } \\
\text { R. G. Brown } \\
\text { J. G. Field } \\
\text { J. S. Lee } \\
\text { S. G. Mckinney } \\
\text { D. M. Nguyen } \\
\text { J. H. Rasmussen } \\
\text { L. M. Sasaki } \\
\text { J. F. Sickels } \\
\text { G. A. Stanton } \\
\text { A. M. Templeton } \\
\text { R. R. Thompson } \\
\text { T.C.S.R.C. }\end{array}$ & $\begin{array}{l}\text { S6-15 } \\
\text { S5-13 } \\
\text { S7-12 } \\
\text { R2-12 } \\
\text { S7-03 } \\
\text { R2-12 } \\
\text { R2-12 } \\
\text { R2-12 } \\
\text { R2-12 } \\
\text { S7-03 } \\
\text { S7-01 } \\
\text { R2-12 } \\
\text { R2-12 } \\
\text { R1-10 }\end{array}$ & $\begin{array}{l}x \\
x \\
x \\
x \\
x \\
x \\
x \\
x \\
x \\
x \\
x \\
x \\
x \\
x \\
x \\
x\end{array}$ & & & \\
\hline $\begin{array}{l}\text { Fluor Hanford } \\
\text { K. E. Be11 } \\
\text { L. A. Burchfield } \\
\text { R. A. Esch } \\
\text { E. Q. Le } \\
\text { K. L. Powe11 } \\
\text { F. H. Steen }\end{array}$ & $\begin{array}{l}T 6-12 \\
T 6-12 \\
T 6-12 \\
\text { S6-72 } \\
\text { T6-04 } \\
\text { T6-12 }\end{array}$ & $\begin{array}{l}x \\
x \\
x \\
x \\
x \\
x \\
x\end{array}$ & & & \\
\hline $\begin{array}{l}\text { Lockheed Martin Services, Inc. } \\
\text { Central Files }\end{array}$ & B1-07 & $x$ & & & \\
\hline $\begin{array}{l}\text { Numatec Hanford Corporation } \\
\text { W. I. Winters }\end{array}$ & T6-07 & $x$ & & & \\
\hline $\begin{array}{l}\text { Office of River Protection } \\
\text { W. Liou } \\
\text { J. A. Poppiti } \\
\text { DOE Reading Room }\end{array}$ & $\begin{array}{l}H 6-60 \\
H 6-60 \\
H 2-53\end{array}$ & $\begin{array}{l}x \\
x \\
x\end{array}$ & & & \\
\hline $\begin{array}{l}\text { Waste Management Federal Serv } \\
\text { S. N. Bakhtiar } \\
\text { D. B. Hardy } \\
\text { J. R. Prilucik }\end{array}$ & $\begin{array}{r}\text { Hanford, I } \\
\text { T6-12 } \\
\text { T6-12 } \\
\text { T6-12 }\end{array}$ & $\begin{array}{l}x \\
x \\
x\end{array}$ & & & \\
\hline
\end{tabular}

